\title{
Die Ritteratur
}

bes neanzebnten Jahrbunderts.

Bweiter Band. 



\section{Die Ritteratur}

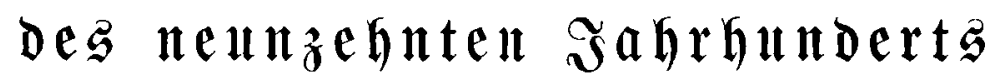

in

\section{ifiren Sauptffrömungen}

Dargeitellt

volt

(beorg Brandes.

3weiter Banb.

Die beutidc romantifare șule.

Sweite Auflage.

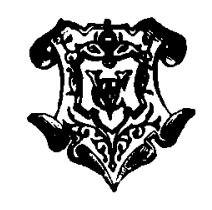

Leip3ig,

Berlag von Beit \& Eomp.

1901. 
Das Mefit ber beraugagabe von itberiebungen borbehalten.

Drud von Mebper \& Wittig in Reipzig. 